\title{
Development of Self-Efficacy for Argumentation Scale*
}

\section{Tartışmaya Yönelik Öz-Yeterlik Ölçeğinin Geliştirilmesi}

\author{
Rabiya KIRAN** iD
}

\section{Eylem YILDIZ-FEYZİoĞLU*** (iD)}

Received: 04 March 2021

Research Article

Accepted: 27 April 2021

ABSTRACT: The aim of the study is to develop a "Self-Efficacy Scale for Argumentation" (SEAS). The participants of the study consisted of 879 pre-service elementary teachers. In order to examine construct validity of SEAS, exploratory factor analysis (EFA) and confirmatory factor analysis (CFA) were utilized. The initial solution of the EFA results revealed that three-factor structure consisting of 24 items called "Effort", "Confidence" and "Determination" for argumentation was obtained. Since the factor-item correlations were not significant for the "Determination" scale ( $\mathrm{p}>.05)$, the two-factor structure consisting of the "Effort" and "Confidence" for argumentation was validated by the repeated CFA. The accepted fit indices for the repeated CFA results were $X^{2} / s d=2.62 ; p<.001 ; \mathrm{RMSEA}=.07 ; \mathrm{S}-\mathrm{RMR}=.05 ; \mathrm{NFI}=.86 ; \mathrm{CFI}=.91 ; \mathrm{GFI}=.87$. The moderate and significant correlation coefficients between the scores of the SEAS with the scale of "Inquiry Learning Skills Perception in Science" (Taşkoyan, 2008) proved the criterion validity of the SEAS. The test-retest reliability of the SEAS was found to be moderate and significant. The internal consistency of SEAS is .93. Finally, a significant difference between the upper and lower groups means that the item discrimination of the SEAS is high.

Keywords: Argumentation, self-efficacy, self-efficacy for argumentation.

ÖZ: Çalışmanın amacı, sınıf öğretmeni adaylarına yönelik “Argümantasyona Yönelik Öz-Yeterlik Ölçeği (AYÖÖ)'nin geliştirilmesidir. Araştırmanın çalışma grubu 879 öğretmen adayı oluşturmuştur. AYÖÖ’nün yap1 geçerliği açıklayıcı faktör analizi (AFA) ve doğrulayıcı faktör analizi (DFA) ile incelenmiştir. İlk AFA sonuçlarına göre, 24 maddeden oluşan ve "Çaba", "Güven" ve "Kararlılık" olarak isimlendirilen üç faktörlü bir yapı elde edilmiştir. "Kararlık" faktörü için faktör-madde ilişkilerinin anlamlı olmaması (p>.05) nedeniyle "Çaba" ve "Güven" olarak iki boyutlu yapının doğrulanması için ikinci kez DFA yapılmıştır. İkinci DFA için kabul gören uyum indeksleri $X^{2} / s d=2.62 ; p<.001$; RMSEA=.07; S-RMR=.05; NFI=.86; CFI=.91; GFI=.87. AYÖÖ ile "Sorgulayıc1 Öğrenme Becerileri Algısı Ölçeği” (Taşkoyan, 2008) ile edilen orta düzeyde ve anlamlı korelasyon katsayıları, AYÖÖ’nün ölçüt geçerliğini ortaya koymuştur. AYÖÖ’nün test-tekrar test sonuçları, ortalama düzeyde ve anlamlı korelasyon katsayıları olduğunu göstermiştir. AYÖÖ’nün iç tutarlık katsayısı .93 olarak hesaplanmıştır. Son olarak, alt ve üst gruplar arasında anlamlı bir farkın bulunması ölçme aracının madde ayırt ediciliğinin yüksek olduğunu göstermektedir.

Anahtar kelimeler: Bilimsel tartışma, öz-yeterlik, tartışmaya yönelik öz-yeterlik.

\footnotetext{
* The manuscript is part of a dissertation named "Examining the Relationship between Pre- Service Teachers' SelfEfficacy towards Discussion, the Nature of Science Beliefs and Critical Thinking." The manuscript is presented at 2nd International Conference on Science, Mathematics, Entrepreneurship and Technology Education 19-22 November, 2020, Bursa, Turkey.

** Corresponding Author: Master of science, Ministry of National Education in Turkey, Mardin, Turkey, rabiaakrn@gmail.com, https://orcid.org/0000-0002-1686-5194

*** Assoc. Prof. Dr, Aydın Adnan Menderes University, Aydın, Turkey, eylemyildiz@adu.edu.tr, https://orcid.org/0000-0002-7051-5232
}

Citation Information

Kıran, R., \& Y1ldız-Feyzioğlu, E. (2021). Development of self-efficacy for argumentation scale. Kuramsal Ĕgitimbilim Dergisi [Journal of Theoretical Educational Science], 14(3), 449-475. 


\section{Scientific Argumentation}

The roots of argument go back as far as Aristotle in Ancient Greek philosophy. Argument, which is grounded in Aristotle's art of rhetoric, is a means used by an individual to reach a conclusion based on the data they have in hand (Billig, 1989; Çelik, 2010; Durhan, 2018; Walton, 2006). Argumentation, however, is a type of discourse by which individuals try to convince each other based on evidence in order to solve a scientific problem (Trend, 2009) since views that differ from one another must exist for an environment of scientific argument to form (van Eemeren et al., 1996). Therefore, Aktamış and Hiğde (2017) defined scientific argument as a type of scientific discourse that consciously includes the components of argument rather than an environment in which individuals present only their views in a simple debate. Throughout this study, the term "scientific argumentation" will be used instead of argumentation. It is seen that besides the concept of scientific argumentation, the concept of argument is also included in the literature, and that these concepts differ from each other. Argument can be understood as a thesis created by the individual to support their idea, whereas scientific argumentation is the name given to the process in which more than one person debates their ideas which are different from each other (Kuhn \& Udell, 2003). While argument is expressed as the claims, data, warrants and backing that themselves contribute to its content, scientific argumentation is expressed as the process of combining these components (Simon et al., 2006). Ceylan (2012) stressed that in a scientific argumentation environment, arguments are required for individuals to convince each other reciprocally.

Researchers such as Zohar and Nemet (2002), Kelly and Takao (2002), Schwarz et al. (2003), Lawson (2003), Sandoval (2003), and Erduran et al. (2004) developed different models for analyzing scientific argumentation in science education. However, in many studies conducted in science education in Turkey, it is seen that Toulmin's model is mostly used (e.g., Karakaş \& Sarıkaya, 2020; Seçkin Kapucu \& Türk, 2019; Tozlu, et al., 2019; Tüzün et al., 2019; Ural et al., 2020). In this study, too, Toulmin's model is used, because in Toulmin's model, since the argument is molded in a certain way, the understanding, analysis and evaluation of the argument are facilitated (van Eemeren et al., 1996). By revealing the mutual relationship between the arguments in a comprehensive way, it is possible for the individual to look critically at the other arguments and at his/her own arguments (Leeman, 1987; Rieke \& Sillars, 1984). According to Aldağ (2006), the Toulmin model can assist students with regard to determining the hypotheses that are not clearly defined in the argument. By extension, it contributes to the development of students' argumentation skills (Toulmin, 1958). Rachmatya and Suprapto (2020) also stated that Toulmin's argument model is of benefit for measuring individual's argumentation skills.

Toulmin's model demonstrates the formation of a claim supported by data and the applicability of these data by using warrants (Jolliff, 1998). According to Toulmin (1958), the components of an argument consist of the claim, data, warrant, backing, qualifier and rebuttal. The claim is a view proposed about an idea, opinion or results. The data are facts put forward to support the claim (Çelik, 2010; Von Aufschnaiter et al., 2008). While the evidence-based justification of the claim with the supporting data is enabled with the warrant, the limits of the validity of the argument are defined with the qualifier (Osborne et al., 2004). While data presented to strengthen the warrants of 
the claim comprise the backing component, the arguments presenting conditions in which the claim is not true confront us as the rebuttal (Erduran et al., 2004). Stating that opposing arguments directed at the claim can be provided with rebuttals, Kaya and Kilıç (2008) stated that these can cause dialogic discussions to begin, since the rebuttals include both the presentation of evidence and reasoning intended to weaken or destroy the opposing argument (Freeley \& Steinberg, 2008). As can be seen, the components of the argument are parts that strengthen the whole and are interdependent like interlocking links. The question of the extent to which the components of scientific argumentation exist or not in the argument determines the power of the argument (Sampson \& Clark, 2008).

\section{Scientific Argumentation in Science Education}

Since scientific argumentation develops the individual's self-efficacy (Eymur \& Çetin, 2017), argumentation skills (İnaltekin \& Akçay, 2017; Osborne et al., 2004), academic achievements (Erkol et al., 2017; Koçak, 2014), willingness to debate (Baydaş et al., 2018), scientific process skills (Er \& Kırınd1, 2020), conceptual understanding (Akyüz, 2018; Hasnunidah et al., 2020), critical thinking (Rosidin et al., 2019; Sönmez, 2017), and attitudes towards science (Walker et al., 2012) occupy an important place in science education. For this reason, scientific argumentation has been included in many reforms in science both in Turkey and all over the world (Erduran \& Msimanga, 2014; Heng et al., 2015).

The Ministry of National Education (MoNE, 2018) in Turkey states that the learning process involves the creation of arguments and that discussion environments should be established to enable individuals to state their claims, support them with warrants, and develop counter arguments to refute the other claims. Although students' participation in the scientific argumentation process is important in terms of both their learning of scientific concepts and their better understanding of the scientific argumentation process, it is reported that opportunities for participation in such discussions is limited (Sampson \& Blanchard, 2012). In this case, the importance of science teachers' knowledge related to scientific argumentation and the teaching of scientific argumentation comes to the fore (Özdem Yilmaz et al., 2017). Studies conducted in this direction reveal the deficiency of teachers' knowledge related to the components of argumentation or the inadequacy of their teaching skills required to initiate, sustain and complete an argument (Aydoğdu \& Buldur, 2013; Hiğde \& Aktamış, 2017; Namdar \& Tuskan, 2018; Sampson \& Blanchard, 2012). Similarly, studies conducted with pre-service teachers are such as to support this finding: there are not only deficiencies in candidates' argument knowledge (Hiğde \& Aktamış, 2017), but they also experience problems in classroom management while planning for scientific argumentation and during implementation of scientific argumentation (Aydeniz \& Özdilek, 2016). According to Martín-Gámez and Erduran (2018), pre-service teachers have difficulty in understanding the rebuttal component, which increases the quality of an argument. Similarly, Gurkan and Kahraman (2018) revealed in their study that although teacher candidates were able to present claims related to a socio-scientific subject, they had difficulties when supporting their claims or refuting other claims. Furthermore, pre-service teachers who participated in the study by Ghebru and Ogunniyi (2017) regarded scientific argumentation only as offering an opinion or as a 
discussion undertaken by individuals in order to get the better of each other regarding a situation.

The abovementioned studies make one wonder how pre-service teachers can structure scientific argumentation in their educational practices. Drawing attention to the relationship between pre-service teachers' self-efficacy and scientific argumentation, Ogan-Bekiroglu and Aydeniz (2013) stated that candidates with high self-efficacy for scientific argumentation could carry out instruction in this direction, whereas candidates with low self-efficacy could use only teacher-centered teaching methods such as direct instruction. This situation reveals that besides environmental factors that can affect pre-service teachers' knowledge and skills related to scientific argumentation, such as the class environment and accessibility of resources, individual characteristics such as self-efficacy, which ensure that they tend not to give up in the face of obstacles and to be successful, also need to be taken into consideration (Purzer, 2011). In the following sections, first of all self-efficacy, and then the relationships between self-efficacy and scientific argumentation are explained.

\section{Self-Efficacy}

Bandura, who argued that self-efficacy forms the basis of human actions, defined self-efficacy as an individual's belief in their competencies to organize and maintain their actions. Self-efficacy belief determines how people feel and think, how they motivate themselves, and how they behave. According to Bandura, when people believe that they cannot achieve the desired result, there is nothing to motivate them towards action (Bandura, 1977, 1994, 2001).

Self-efficacy belief focuses on the ability to carry out a certain task successfully and is assumed to be a powerful predictor of behavior (Woolfolk, 2016). While selfefficacy affects an individual's goals and behaviors, it is also affected by actions and conditions in the environment; that is, self-efficacy has an effect on people's behaviors and the environments they interact with, and is also itself affected by actions and conditions in those environments. Consequently, behaviors and environments complement each other reciprocally (Schunk \& Meece, 2006; Schunk \& Miller, 2002).

Individuals' beliefs in their ability inform us about how they interpret the opportunities and difficulties around them. It is associated with which problems they will tackle, how much they will strive for their goals, how patient they can be in the face of difficulties, and whether failure situations will be demoralizing or motivating for them (Bandura, 2002, 2006). For example, people who feel competent to carry out a certain task are more willing to take part in activities and to work harder, and are more determined to find a solution when faced with difficulties (Schunk \& Miller, 2002). As well as affecting the amount of effort individuals will spend and the extent to which they will be able to withstand difficult conditions, self-efficacy also has an effect on whether they will be able to deal will these difficulties (Poulou, 2003). Bandura (1986, 1997) explained the sources of self-efficacy in four parts, namely individuals' own performance accomplishments, vicarious experiences, verbal persuasion and physiological states. According to Bandura (1977), individuals' own performance accomplishments are the most important source that forms their self-efficacy belief. While performances that individuals interpret as successful increase their self-efficacy, results that are perceived as failures decrease their self-efficacy (Chen \& Yeung, 2015). 
By means of indirect experiences, individuals also make inferences about their abilities by observing their peers. When students who observe their peers see that they can perform a task, they show a tendency to believe that they will also be able to do it themselves (Schunk \& Miller, 2002). Verbal persuasion is concerned with feedback from other people regarding individuals' ability to accomplish a task. When individuals receive positive feedback, their self-efficacy is supported, whereas negative feedback can lower their self-efficacy (Bandura, 1977; Chen \& Yeung, 2015). As well as these, individuals may also consider their emotional and physiological states while evaluating their self-efficacy. Drawing attention to the fact that individuals' performances can be interpreted as weak in stressful situations, Bandura (1994) mentioned that they might name aches and pains as physical weakness in activities that involve strength and resistance.

\section{Self-Efficacy for Argumentation}

In argumentation, individuals challenge each other with claims and the reasons for these claims. Argumentative environments are complex environments that involve cognitive conflicts, doubts, complex decisions, etc. While individuals form their claims, they also create counter-claims by thinking about other individuals' ideas (Mirza \& Perret-Clermont, 2012). For this reason, rather than accepting a viewpoint without considering it (van Eemeren et al., 2014), scientific argumentation requires individuals to ground their claims, make statements related to counter-claims, evaluate alternative ideas, and reconstitute their own ideas (Chin \& Osborne, 2010). This situation causes individuals to make a decision about whether or not to use their argumentation skills by bringing their self-efficacy belief to light (Erika et al., 2019). Therefore, learning environments that are based on scientific argumentation, while increasing individuals' interest in science by allowing them to investigate and solve a problem that they have identified, give them the opportunity to feel competent by allowing them to take responsibility for their own learning (Choi et al., 2015).

In argumentation activities, individuals can gain experience in forming arguments in cooperation, producing evidence, evaluating alternative arguments, and projecting the results of their arguments (Simon et al., 2012). As well as examining preservice teachers' practice activities, Çetin et al. (2016) also stressed the importance of determining their self-efficacy beliefs. The model applied by Erika et al. (2018) for developing pre-service chemistry teachers' self-efficacy and argumentation skills improved both the candidates' argument-forming skills and their self-efficacy. Again, it was observed that self-efficacy developed in pre-service teachers who did experiments related to science subjects during laboratory practices based on scientific argumentation (Karslı Baydere \& Şahin Çakır, 2019). Voica et al. (2020) reported that in an environment based on problem-solving, pre-service teachers' perceived self-efficacy triggered motivation to persevere, and that when the candidates took on a new task, their self-efficacy increased and their self-confidence improved.

Individuals who do not possess cognitive and social skills related to initiating, sustaining and evaluating an argument may experience a feeling of difficulty in an argumentation environment. In such situations, which they generally perceive as a risk for themselves, individuals may avoid entering such environments in order to cope with the feeling of failure that they will experience (Mirza \& Perret-Clermont, 2012). Pre- 
service teachers' previous teacher-centered learning experiences in their university education may lead them to feel inadequate at coping with the problems that scientific argumentation will bring them. Thus, they refrain from scientific argumentation practices. For example, Hewson and Ogunniyi (2011) stated that although the instructor provided candidates with certain experiences for them to use scientific argumentation as a means of instruction, there would be a need for in-service training for candidates to use this new approach, which they regarded as radical for themselves, in their classes. Therefore, individuals' belief that they can use these skills to make their argumentation skills ready for use must be sufficient (Erika \& Prahani, 2017).

Furthermore, when rebuttals of an argument occupy a great deal of space during argumentation, this means that the disputed ideas are investigated more. In this situation, so that individuals who argue can protect their positions in a powerful way, their self-efficacy beliefs in their argumentation skills need to be strong (Garcia-Mila et al., 2013). If individuals think the opposite, that is, if they believe that they cannot succeed in a task or activity, they may not wish to take action in the face of difficulties (Bandura, 1999). Considering that actions are first considered at the anticipation stage, individuals' self-efficacy belief will also affect their knowledge and skills related to argumentation (Bandura, 1994). Uçar and Demiraslan Çevik (2020) reported that since pre-service teachers who participated in their study did not trust themselves in terms of their argumentation skills, the feedback that they gave each other regarding the argumentation map that was developed was not effective in developing their argumentation skills. For this reason, to make teacher candidates' understanding, knowledge and skills related to argumentation more comprehensible, it is also necessary to examine candidates' self-efficacy for argumentation.

When the literature is examined, in terms of measuring self-efficacy in the field of science, a number of examples can be found, such as a science teaching self-efficacy belief scale, an environmental education self-efficacy scale (Özlü et al., 2013), a selfefficacy scale for laboratory practices in science teaching (Aka, 2016), a self-efficacy belief scale related to knowledge and instruction of the nature of science (Tatar \& Özenoğlu, 2018), and a laboratory self-efficacy scale (Akkuş, 2020). Moreover, there are also studies related to developing pre-service teachers' competences for science (Kazempour \& Sadler, 2015; Knaggs \& Sondergeld, 2015; Menon \& Sadler, 2016), teaching science (Hechter, 2011; Mulholland \& Wallace, 2001; Narayan \& Lamp, 2010; Palmer, 2006; Ramey-Gassert \& Shroyer, 1992; Velthuis et al., 2014) and the factors affecting the argumentation instruction (Atabey et al., 2020). Furthermore, it is determined that scientific argumentation studies conducted with pre-service teachers focus on teacher competency (Aydeniz \& Özdilek, 2016; Ecevit \& Kaptan, 2019; OganBekiroglu \& Aydeniz, 2013), competency for the subject of science (Öztürk, 2013), or on determining perceptions related to scientific argumentation (Lytzerinou \& Iordano, 2020; Sadler, 2006) and attitude for discussion ability (Ocak \& Karakuş, 2015). In summary, although the effects of argument-based learning environments on pre-service teachers have been studied, it seems that it is not possible to determine how pre-service teachers' self-efficacy for argumentation changes. Based on this, the aim of this study is to develop a "Self-Efficacy for Argumentation Scale" (SEAS) for pre-service teachers. The SEAS that is developed is of importance for a more extensive evaluation of 
scientific arguments. Moreover, the SEAS is important because it is original in combining scientific argumentation and self-efficacy included in the literature.

\section{Method}

\section{Study Group}

The study group consisted of 1st, 2nd, 3rd and 4th grade pre-service elementary teachers attending two public universities located in the Aegean Region in the spring semester of the 2018-2019 academic year (Table 1). The sample of the study consists of 858 pre-service teachers (or teacher candidates) studying in the first, second, third and fourth classes of the Primary Education Department of Aydın Adnan Menderes University, Dokuz Eylül University, Muğla Sıtkı Koçman University, Pamukkale University and Afyon Kocatepe University. Convenience sampling is a method in which the researcher selects the participants herself/himself (Fraenkel et al., 2011). It can also be defined as choosing the sample from easily and accessible units that can be applied (Büyüköztürk, 2012). In the study, the sample was limited to the specified universities by considering the distance and time variables between the universities in the region and the city of Aydin. After the necessary permission for the research had been obtained, the scale was given to the pre-service elementary teachers specified in Table 1.

Table 1

Distribution of Study Group by Stages

\begin{tabular}{lc}
\hline Stage of Study & Participants \\
\hline Pilot study stage & 80 \\
Exploratory factor analysis & 206 \\
Confirmatory factor analysis & 307 \\
Criterion validity & 216 \\
Test-retest & 70 \\
Total & 879 \\
\hline
\end{tabular}

\section{Creation of Item Pool}

The theoretical framework of the SEAS was developed by considering Toulmin's (1958) scientific argumentation model and the feeling competent, endeavor and determination subdimensions of self-efficacy (Pajares, 1997). According to Toulmin, while the basic components of scientific argumentation consist of the claim, data and warrant, when the arguments become more complex, the backing, qualifier and rebuttal components are also included in the process. Bandura $(1994,1997)$, who argued that individuals shape their actions according to their self-efficacy, stated that selfefficacy is effective in individuals' endeavors and their ability to continue their actions in a determined way. Therefore, the scale items were written according to the endeavor, feeling competent and determination subdimensions of self-efficacy, and were organized according to the components of argumentation (Fig. 1).

While the items were being created, care was taken to ensure that they were clear and understandable, and that one item did not include more than one judgment (Karakoç \& Dönmez, 2014). Since self-efficacy is concerned with an individual's belief 
in their competence to carry out an action, Bandura (2006) stated that it would be inappropriate for items related to self-efficacy to be negatively biased.

Figure 1

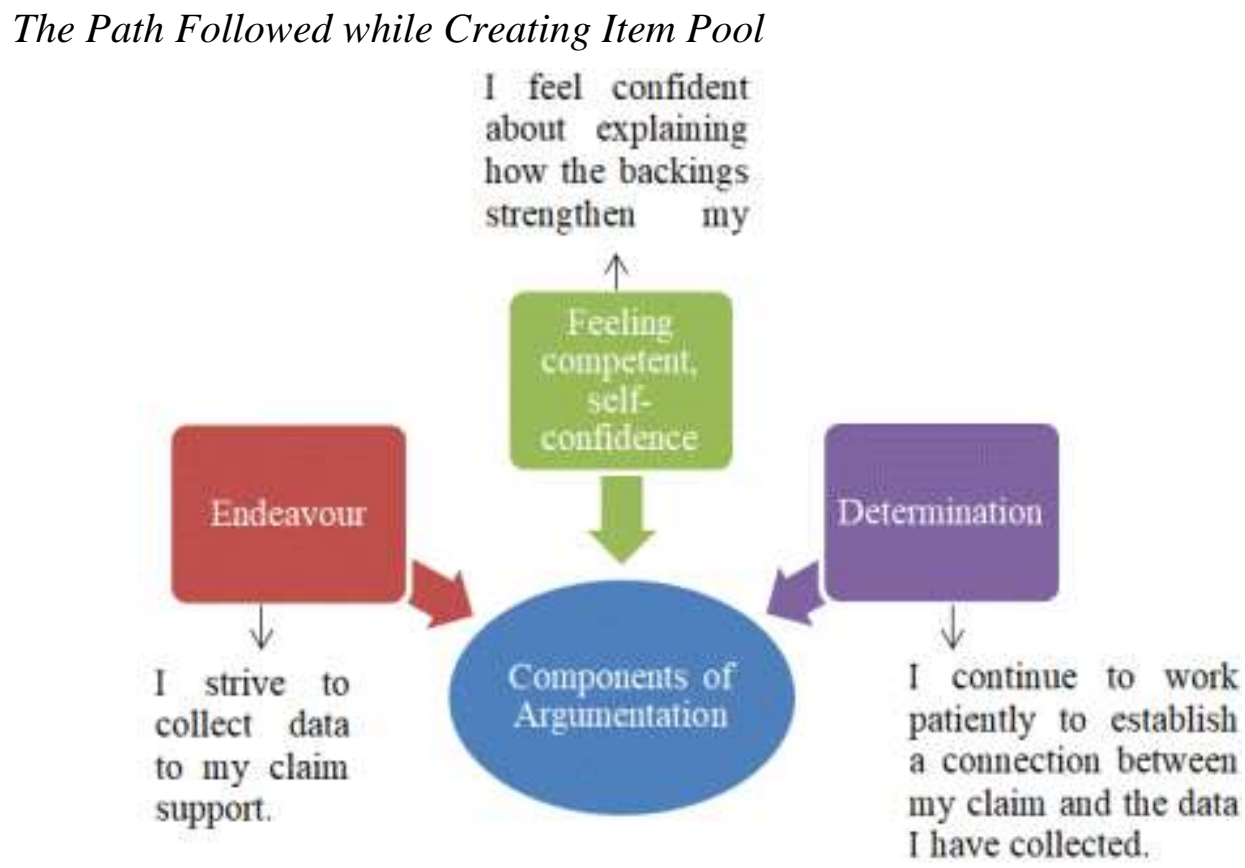

For this reason, writing negative items was avoided. While the components of scientific argumentation and the subdimensions of self-efficacy were being combined, each component of scientific argumentation was combined with the subdimensions of self-efficacy. While writing the items for the claim component, items show that in a learning environment where this component is found, an individual feels competent, makes an effort, and shows determination while using this component. By taking all of these into account, 91 items were included in the created item pool. The scale items were prepared in such a way that candidates would respond according to a 5-point Likert-type scale, and are scored as "Strongly agree" (1), "Agree" (2), "Undecided" (3), "Agree" (4), and "Strongly agree" (5).

\section{Pilot Study Stage}

To check the comprehensibility of the 91-item scale, a pilot study was conducted with students in Classroom Teaching at the Elementary Education Department of Adnan Menderes University. For the pilot study of the SEAS, the 91-item scale was administered to 80 pre-service teachers. The teacher candidates were given 25 minutes for the implementation. During the implementations, the researcher stressed the difference between scientific argumentation and argument to the candidates, and after this explanation, the candidates responded to the items. The feedback that came from the candidates revealed that the items were understandable and that no problems had been experienced during the implementation of the scale.

\section{Data Analysis}

Studies related to the validity of the developed scale were evaluated by using content validity, construct validity and criterion validity. For content validity, the views 
of 5 experts in the field of science education were obtained, while for construct validity, "Exploratory Factor Analysis" was performed. In order to check the constructs that emerged with the exploratory factor analysis of the scale, "Confirmatory Factor Analysis" was performed. Criterion validity was enabled by using the "Perception Scale for Inquiry Learning Skills" developed by Taşkoyan (2008).

The calculations for the reliability studies were made by examining the "TestRetest Method", the "Cronbach Alpha Internal Consistency Coefficient", and the "Item Discrimination" characteristic. For analysis of the items, the upper 27\%-lower $27 \%$ group method was utilized. The data were analyzed using the SPSS 18.0 and Lisrel 8.80 software programs. The data related to the validity and reliability of the "SEAS" that was developed for the study are included in the findings section.

\section{Ethical Procedures}

Ethical approval and written permission were obtained from the Educational Research Ethics Committee; Adnan Menderes University (dated 29.01.2019 and numbered 2019-02).

\section{Results}

\section{Findings Related to Content Validity}

For content validity, to examine the candidate items created in terms of content, meaning and orthography, an "Expert Evaluation Form" was prepared and sent to five faculty members in the field of science education. The researchers were asked to make statements on the form as to the appropriateness or inappropriateness of the items and to add their views or suggestions. Following the evaluation, the number of items was reduced from 91 to 73 due to more than one item measuring the same characteristic or the inappropriateness of items for the targeted content on the scale. Again, in line with the expert views, items including more than one judgment statement for a single item, and items containing words that created ambiguity in a sentence or having an inverted structure in terms of meaning were amended. As a result, the scale's construct validity, which was given its final form with 73 items, was ready to be tested.

\section{Findings Related to Construct Validity}

Construct validity can be defined as evidence that a measurement tool has measured the construct that it is intended to measure (Brown, 2000). One of the methods most frequently used to test construct validity is factor analysis (Büyüköztürk et al., 2016).

\section{Exploratory Factor Analysis}

To perform the exploratory factor analysis of the SEAS, the 73-item scale was administered to 206 pre-service elementary teachers studying at Adnan Menderes University. It was seen that the scale data exhibited normal distribution (Skewness=.173, Kurtosis=.024). To check the suitability of the data for factor analysis, the results of the Kaiser-Meyer-Olkin (KMO) coefficient and Bartlett sphericity tests were examined (Leech et al., 2005). By finding a KMO value of .94 for the group with whom the scale was implemented, it was determined that the sample size was adequate (Liu et al., 2021). By finding a Bartlett test result of .000, it was seen that the required 
value had been achieved (Can, 2016; Leech et al., 2005). In the principal components analysis that was conducted to determine the factor structure of the scale, it was seen that a 15-factor structure appeared (Fig. 2).

Figure 2

Scree Plot Graph of SEAS with 15-Factor Structure

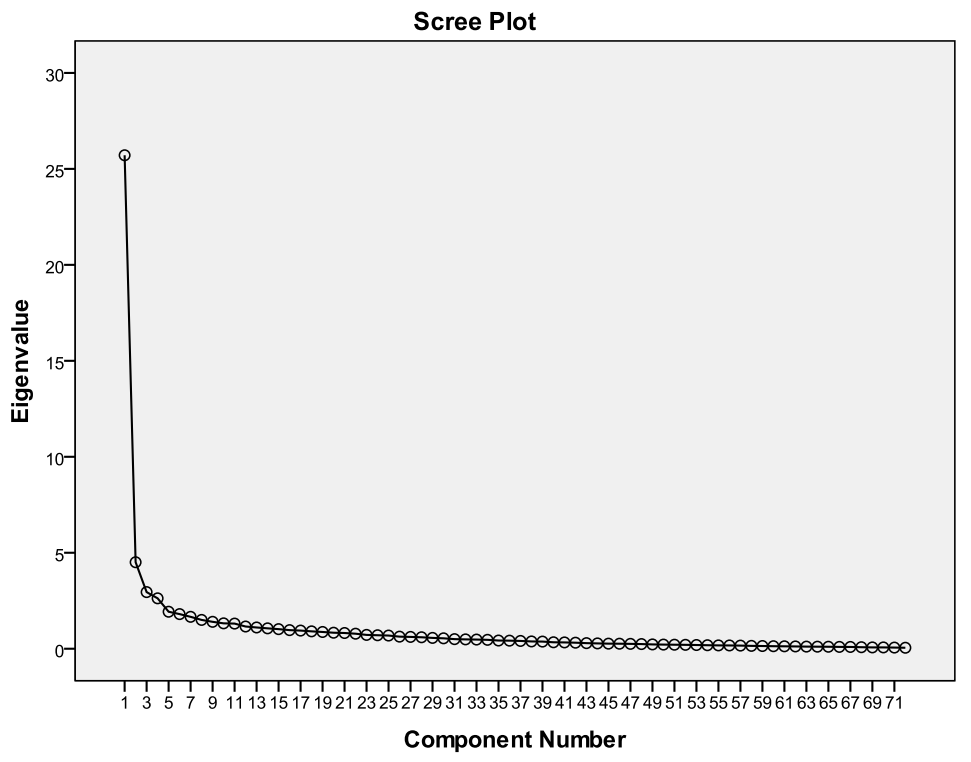

According to Fig. 2, these factors explain $72.795 \%$ of the variance. Varimax rotation was performed on the 15-factor structure created, and items with values below .45 and items having a difference of less than .10 between factor loadings loaded on more than one factor were removed from the scale (Büyüköztürk, 2018). As a result, 49 items that did not conform to the criteria were removed from the scale. Consequently, a three-factor structure consisting of 24 items was obtained, and since items forming the first factor gathered items in the form of "I endeavour" and "I strive", it was considered appropriate to name this item effort for argumentation; since the second factor gathered items in the form of "I feel competent" and "I am confident", it was considered suitable to name this item confidence for argumentation; and since the third factor gathered items in the form of "I carry on working" or "I do not give up", it was considered appropriate to name this item determination for argumentation.

\section{Confirmatory Factor Analysis}

Following the exploratory factor analysis, confirmatory factor analysis was performed for the 24-item scale in order to test the model that was created. To test the three-factor structure of the developed scale, the confirmatory factor analysis was carried out with data obtained from pre-service science teachers studying at Adnan Menderes University and 307 pre-service classroom teachers studying at Muğla Sitk1 Koçman University. The analysis results for these data were calculated as $x^{2} / s d=1.97$ $\mathrm{RMSEA}=.068, \mathrm{GFI}=.84, \mathrm{CFI}=.97$, IFI=.97, NFI=.94, RMR=.036, $\mathrm{SRMR}=.063$, and $\mathrm{NNFI}=.97$. In addition, the correlation coefficients between the factors were examined, and the correlation between the scores obtained from the effort for argumentation and confidence for argumentation factors was determined to be .60 and significant $(p<.001)$. 
However, the correlation between the scores obtained from the determination for argumentation factor and the scores obtained from the effort for argumentation and confidence for argumentation factors was calculated.10. When the factor-item correlations are examined, the factor-item correlations for all items included in the effort for argumentation and confidence for argumentation factors were significant at a level of .05 , while these correlations were not significant for the determination for argumentation factor $(p>.05)$. As a result, it was concluded that the three-factor structure obtained was not valid, and the three items belonging to the determination for argumentation factor were removed from the scale. To test the validity of the two-factor structure consisting of the effort for argumentation and confidence for argumentation factors, confirmatory factor analysis was again performed on the data obtained from 216 pre-service elementary science teachers attending Adnan Menderes University. The goodness-of-fit values obtained from the repeated confirmatory factor analysis are reported in Table 2.

Table 2

Results of Confirmatory Factor Analysis of Two-Factor Structure

\begin{tabular}{lc}
\hline Evaluation Criteria & Results \\
\hline$X^{2} / s d$ & 2.62 \\
RMSEA & .07 \\
CFI & .91 \\
RMR & .01 \\
SRMR & .05 \\
NFI & .86 \\
IFI & .91 \\
NNFI & .90 \\
GFI & .87 \\
\hline
\end{tabular}

Examination of Table 2 shows that by determining the $X^{2} / s d$ value as below 3, the RMSEA value as .07, and the RMR and SRMR values as .05 and below, a good level of fit was obtained. Moreover, the fact that the NFI, NNFI, IFI, CFI and GFI values were determined to be very close to .90 or above .90 indicates that a good degree of fit was achieved (Bentler \& Bonnet, 1980; Browne \& Cudeck, 1989; Byrne, 1998; Hu \& Bentler, 1999; Schumacker \& Lomax, 2004). Fig. 3 shows the path diagram for the confirmatory factor analysis of the SEAS. 
Figure 3

Path Diagram for Confirmatory Factor Analysis of SEAS

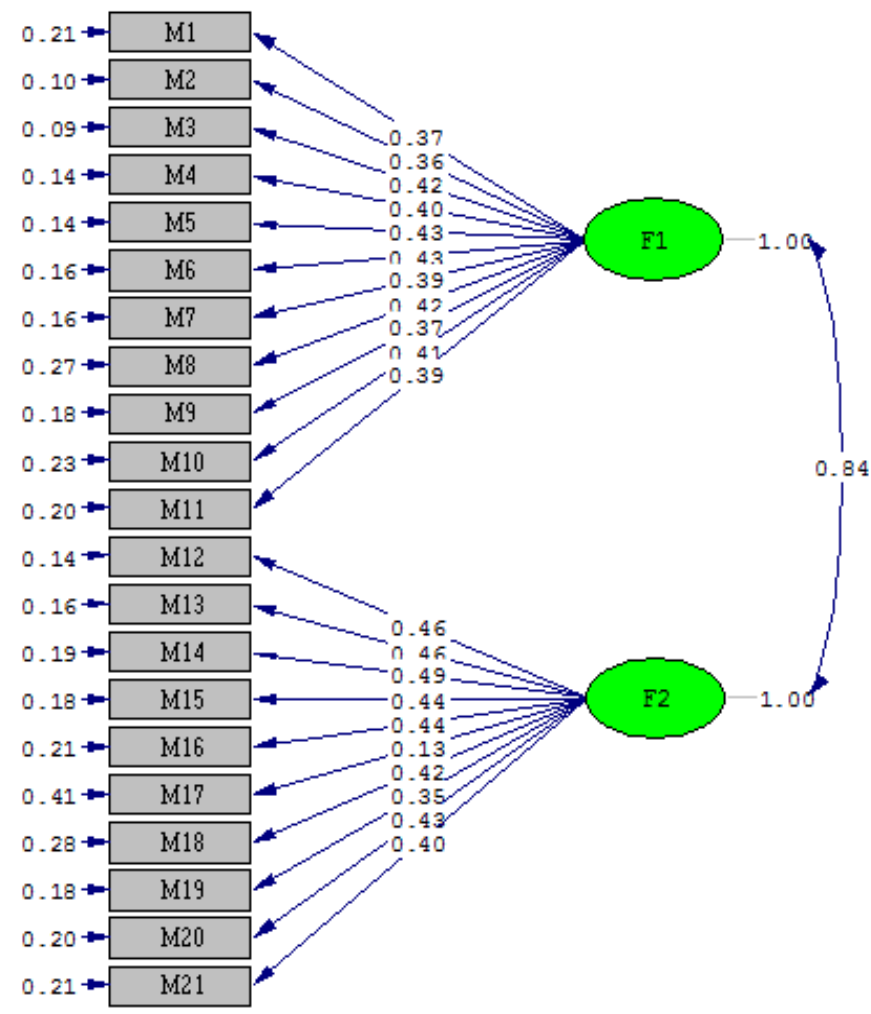

Note: (F1: Effort for argumentation; F2: Confidence for argumentation)

\section{Item Loading Values of Factors}

The factor named effort for argumentation consists of 11 items. The factor loadings of the items included in this factor range between .610 and .844 . This factor explains $31.076 \%$ of the variance with an eigenvalue of 6.526 . The factor named confidence for argumentation consists of 10 items. The factor loadings of the items included in this factor range between .650 and .790 (Table 3). This factor explains $27.438 \%$ of the variance with an eigenvalue of 5.762. The final version of the scale consisting of 21 items explains $58.51 \%$ of the variance.

Table 3

Item Loading Values of SEAS

\begin{tabular}{ccc}
\hline Items & Confidence for Argumentation & Effort for Argumentation \\
\hline I 60 & .790 \\
I 58 & .769 \\
I 33 & .736 \\
I 27 & .734 \\
I 42 & .731 \\
I 2 & .702 \\
I 38 & .681 \\
\hline
\end{tabular}




$\begin{array}{lll}\text { I } 28 & .667 & \\ \text { I } 22 & .655 & \\ \text { I } 8 & .650 & .844 \\ \text { I } 13 & & .839 \\ \text { I } 14 & & .826 \\ \text { I } 15 & & .815 \\ \text { I } 12 & & .766 \\ \text { I } 17 & .732 \\ \text { I } 18 & .723 \\ \text { I } 31 & .657 \\ \text { I } 4 & & .632 \\ \text { I } 29 & .612 \\ \text { I } 34 & .610 \\ \text { I } 24 & \end{array}$

\section{Findings Related to Criterion Validity}

For the criterion validity of the scale, the "Perception Scale for Inquiry Learning Skills" developed by Taşkoyan (2008) was used. To determine whether the SEAS had criterion validity, the 21 -item scale was administered to 216 pre-service science teachers attending the Science Teaching Department of Adnan Menderes University Education Faculty. The relationship between the scores obtained by the candidates from the Perception Scale for Inquiry Learning Skills and the scores they obtained from the effort and confidence factors of the SEAS was examined with the Pearson product moment correlation coefficient. The results obtained are presented in Table 4.

Table 4

Correlation of SEAS with Perception Scale for Inquiry Learning Skills

\begin{tabular}{lc}
\hline Factors & Perceptions of Inquiry Learning Skills \\
\hline Effort for argumentation & .66 \\
Confidence for argumentation & .61 \\
General Scale & .66 \\
\hline
\end{tabular}

$* p<.001$

According to Table 4, the correlation coefficients obtained are moderate and significant (Köklü et al., 2007). This shows that the validity of the SEAS conformed with the tested criterion.

\section{Findings Related to Test-Retest Method}

For the reliability study of the scale, the test-retest method was used. The scores obtained with this method show how consistent they are (Table 5, Büyüköztürk et al., 
2016). The test-retest was implemented with a different study group. 70 pre-service classroom teachers attending Adnan Menderes University were required to voluntarily use assigned names, and one month after the first implementation was made, the test was implemented for a second time with the same group. During the second implementation, some pre-service teachers either forgot their assigned names or did not participate in the second implementation. Therefore, by excluding 16 teacher candidates from the study, the data of the remaining 54 pre-service teachers were analyzed with the Pearson's correlation coefficient.

Table 5

Test-Retest Results for SEAS

\begin{tabular}{llc}
\hline Subdimensions & $N$ & $R$ \\
\hline Effort for argumentation & 54 & $.704^{* *}$ \\
Confidence for argumentation & 54 & $.662^{* *}$ \\
General mean & 54 & $.696^{*}$
\end{tabular}
$* * p<.001, * p<.05$

\section{Findings Related to Cronbach Alpha Reliability Coefficient}

One of the reliability studies of the scale was made by calculating the Cronbach alpha reliability coefficient. This method is used to test the reliability of test scores, and is especially used in cases where responses are obtained from a rating scale. It shows the extent to which the test items are consistent with the general measurement (Büyüköztürk et al., 2016). Karakoç and Dönmez (2014) and Fraenkel et al. (2011) stated that the calculated coefficient should be at least .70 of the general acceptance. According to George and Mallery (2016), the closer the alpha is to 1, the higher the internal consistency of the scale. While a Cronbach alpha reliability coefficient of .93 was found for the general scale, the reliability coefficients of the effort for argumentation and confidence for argumentation factors were determined to be .92 and .91 , respectively (Table 6 ). The obtained values indicate that the reliability coefficients of the general scale and its subdimensions are "excellent" according to George and Mallery (2016).

Table 6

\section{Cronbach Alpha Reliability Coefficient for the Scale}

\begin{tabular}{lcc}
\hline Subdimensions & Number of Items & Cronbach's Alpha \\
\hline Effort for argumentation & 11 & .92 \\
Confidence for argumentation & 10 & .91 \\
General scale & 21 & .93 \\
\hline
\end{tabular}

\section{Findings Related to Item Discrimination}

To determine the item discrimination strength of the scale, the lower $27 \%$ and upper $27 \%$ groups formed according to the total scores of the test were determined. Then, to reveal whether the difference between the mean scores of the lower $27 \%$ group 
$(n=56)$ and the upper $27 \%$ group $(n=56)$ was significant, independent groups t-test was performed. The $\mathrm{p}$ value of Levene's test, which checks the equality of the group variances, was found to be .582 . Therefore, since $p>0.05$, the variances were accepted as equal. As a result of the t-test that was performed between the lower and upper $27 \%$ groups, a statistically significant difference was determined between them $\left(t_{(110)}=23.29\right.$, $p<.001$ ). A significant difference found between lower and upper groups indicates that the item discrimination of the measurement tool is high.

Furthermore, to determine the extent to which the discrimination of each item in the scale was adequate in terms of the characteristic that it measured, t-test for independent groups was performed in the lower and upper $27 \%$ groups for each item. The results are shown in Table 7.

Table 7

Independent T-test Results between Item-Total Correlations of Factors of SEAS and Lower 27\% - Upper 27\% Scores

\begin{tabular}{lccc}
\hline Subdimensions & Item No. & $\begin{array}{c}\text { Item-Total (Upper 27\% } \\
\text { Lower 27\%) Correlation }\end{array}$ & $\begin{array}{c}t \text {-Value } \\
\text { for Items }\end{array}$ \\
\hline & 2 & .734 & $2.226^{*}$ \\
Effort for argumentation & 5 & .674 & $1.936^{*}$ \\
& 6 & .688 & $1.803^{*}$ \\
& 8 & .634 & $2.755^{*}$ \\
& 12 & .541 & $2.653^{*}$ \\
& 14 & .607 & $4.536^{* *}$ \\
& 16 & .664 & $3.601^{* *}$ \\
& 17 & .684 & $3.423^{*}$ \\
& 18 & .632 & $2.602^{*}$ \\
& 19 & .616 & $3.200^{*}$ \\
& 21 & .663 & $2.157^{*}$ \\
& 1 & .497 & $3.824^{* *}$ \\
& 3 & .565 & $4.490^{* *}$ \\
& 4 & .601 & $4.737^{* *}$ \\
& 7 & .568 & $2.901^{*}$ \\
& 9 & .696 & $5.626^{* *}$ \\
& 10 & .578 & $1.777^{*}$ \\
& 11 & .632 & $2.941^{*}$ \\
& 13 & .693 & $4.430^{* *}$ \\
& & .632 & $3.710^{* *}$ \\
& & & $2.956^{*}$ \\
\hline
\end{tabular}

$* p<.05, * * p<.001$ 
As a result of the analysis, significant differences were found between the upper $27 \%$ and lower $27 \%$ groups for all items $(p<.05, p<.001)$. Accordingly, it can be said that every item in the scale is discriminatory in measuring the characteristic that is desired to be measured.

\section{Discussion and Conclusion}

In this study, a validity and reliability study of the Self-Efficacy for Argumentation Scale for pre-service classroom teachers has been made. Studies examining the self-efficacy of pre-service teachers in argumentation environments within the scope of socio-scientific subjects determine candidates' self-efficacy for arguments requiring knowledge in a certain field (Çetin et al., 2014; Iordanou \& Constantinou, 2014). However, since the SEAS developed in this study can measure pre-service classroom teachers' self-efficacy independently of their field knowledge, it is suitable for use by researchers in both experimental and survey-type argumentationrelated studies in which different field knowledge is included. On the other hand, since studies conducted to improve pre-service teachers' self-efficacy for argumentation (Ogan-Bekiroglu \& Aydeniz, 2013; Özdem et al., 2013) deal with argumentation as a teaching skill, it is not directly known how the candidates' self-efficacy for argumentation changes. For this very reason, it is considered that the SEAS will contribute to the literature, since it aims to measure pre-service teachers' self-efficacy for argumentation with regard to their effort and confidence.

To ensure the validity of the scale, content validity and construct validity were tested. While content validity was enabled with five faculty members who were experts in the field, exploratory and confirmatory factor analysis were used for construct validity. While the results of the exploratory factor analysis revealed a three-factor structure, namely effort for argumentation, confidence for argumentation and determination for argumentation, the results of the confirmatory factor analysis revealed a two-factor structure in the form of effort for argumentation and confidence for argumentation. Moreover, for the scale validity, correlation between two scales was calculated using the Perception Scale for Inquiry Learning Skills (Taşkoyan, 2008). While the correlation of the effort for argumentation factor with the Perception Scale for Inquiry Learning Skills was .66, the correlation of the confidence for argumentation factor with the scale was .61. It was determined that the .66 correlation between the SEAS and the Perception Scale for Inquiry Learning Skills was moderate and significant (Köklü et al., 2007). For the reliability analyses of the scale, the test-retest method was applied. Accordingly, by observing that the correlation coefficients based on the general scale and its subdimensions were moderate and significant, it was determined that the scale has a consistent structure. Cronbach alpha internal consistency coefficients were calculated as .93 for the general scale, .92 for effort for argumentation, and .91 for confidence for argumentation, respectively, and consequently, it was determined that the internal consistency is very high (George \& Mallery, 2016). Furthermore, by determining that there was a significant difference between the lower $27 \%$ group and upper $27 \%$ group, it was seen that the item discrimination of the measurement tool was high. The lowest and highest scores that can be obtained from the scale are 21 and 105, respectively. It takes approximately 10 minutes to respond to the scale. 
While Pajares (1997) noted that feeling competent, making an effort and showing determination are dimensions of self-efficacy, Bandura $(1994,1997)$ stated that individuals shape their actions according to their self-efficacy and that their selfefficacy is effective for their endeavours and continuing their actions in a determined way. Taking this framework into consideration, the effort and confidence subdimensions of the SEAS conforms to the constructs put forward for explaining selfefficacy. However, since the scale does not include a determination factor for selfefficacy, researchers may feel the need to collect additional data when applying it. In this way, it will be possible to ascertain how determined candidates are to overcome difficulties they encounter in learning environments or how sustainable their desire to learn is. Together with this limitation, considering that in the literature, argumentation and self-efficacy are each discussed as separate study topics in both experimental and survey-type studies, it is recommended that researchers who wish to deal with the two study topics together use the SEAS. The final version of the scale is presented in Appendix 1.

\section{Implications}

If pre-service teachers' self-efficacy is considered as individual characteristics, these characteristics are also related to behavior and the environment. Therefore, apart from individuals' perceptions, what they know about argumentation can be determined with data obtained directly from argumentation-based learning environments, since the presence or absence of argumentation-based instruction in the classroom environment in which an individual is found can affect that individual's level of knowledge and therefore, his/her self-efficacy. For this reason, it is considered necessary also to investigate how pre-service teachers perceive the classroom environment for argumentation and what kind of environment they are actually involved in.

\section{Acknowledgments}

The funding of this study is supported by Scientific Research Projects Unit of Adnan Menderes University under Grant \# EĞF- 18002.

\section{Statement of Responsibility}

All authors have participated sufficiently in the work to take public responsibility for the content, including participation in the concept, design, analysis, writing, or revision of the manuscript. Furthermore, each author certifies that this manuscript has not been and will not be submitted to or published in any other publication before its appearance in the Journal of Theoretical Science. 


\section{References}

Aka, E. İ. (2016). An investigation into prospective science teachers' attitudes towards laboratory course and self-efficacy beliefs in laboratory use. International Journal of Environmental \& Science Education, 11(10), 3319-3331.

Akkuş, A. (2020). Laboratuvar öz yeterlik ölçeği geliştirme çalışması. Yüzüncü $Y_{\imath l} l$ Üniversitesi Eğitim Fakültesi Dergisi, 17(1), 991-1014. https://doi.org/10.33711/yyuefd.800917

Aktamış, H., \& Hiğde, E. (2017). Argümantasyon nedir? In H. Aktamış (Ed.), Örnek etkinliklerle fen eğitiminde argümantasyon (pp. 7-27). Anı Publications.

Akyüz, M. (2018). Argümantasyon tabanlı ögrenme ortamlarının sinıf öğretmen adaylarının kavramsal anlamalarına etkisi genetiği değiştirilmiş organizmalar örneği (Unpublished master's thesis dissertation). Karadeniz Teknik Üniversitesi.

Aldağ, H. (2006). Toulmin tartışma modeli. Çukurova Üniversitesi Sosyal Bilimler Enstitüsü Dergisi, 15(1), 13-34.

Atabey, N., Topçu, M. S., \& Çiftçi, A. (2020). Adaptation of the scale of the factors affecting argumentation instruction into Turkish. Journal of Theoretical Educational Science, 13(2), 352-368.

Aydeniz, M., \& Özdilek, Z. (2016). Assessing and enhancing pre-service science teachers' self-efficacy to teach science through argumentation: Challenges and possible solutions. International Journal of Science and Mathematics Education, 14, 1255-1273. https://doi.org/10.1007/s10763-015-9649-y

Aydoğdu, B., \& Buldur, S. (2013). Sınıf öğretmeni adaylarının bilimsel süreç becerilerinin bazı değişkenler açısından incelenmesi. Kuramsal Eğitimbilim Dergisi, 6(4), 520-534. http://dx.doi.org/10.5578/keg.6713

Bandura, A. (1977). Self-efficacy: Toward a unifying theory of behavioral change. Psychological Review, 84, 191-215. https://doi.org/10.1016/0146-6402(78)90002-4

Bandura, A. (1986). Social foundation of thought and action: A social cognitive theory. Prentice-Hall.

Bandura, A. (1994). Self-efficacy. In V. S. Ramachaudran (Ed.), Encyclopedia of human behavior (pp. 71-81). Academic Press.

Bandura, A. (1997). Self-efficacy: The exercise of control. W.H. Freeman.

Bandura, A. (1999). A sociocognitive analysis of substance abuse: An agentic perspective. Psychological Science, 10 (3), 214-217.

Bandura, A. (2001). Social cognitive theory: An agentic perspective. Annual Review of Psychology, 52, 1-26. https://doi.org/10.1111/1467-839X.00024

Bandura, A. (2002). The growing primacy of perceived efficacy of human selfdevelopment, adaptation and change. European Psychologist, 7(1), 2-16.

Bandura, A. (2006). Adolescent development from an agentic perspective. In F. Pajares, \& T. Urdan (Eds.), Self-efficacy beliefs of adolescents (pp. 1-43). Information Age Publishing.

Baydaş, Ö., Yeşildağ-Hasançebi, F., \& Kilis, S. (2018). Argümantasyon tabanlı bilim öğrenme yaklaşımında üniversite öğrencilerinin tartışma süreçlerinin incelenmesi. İnönü Üniversitesi Eğitim Fakültesi Dergisi, 19(3), 564-581. https://doi.org/10.17679/inuefd.341522 
Bentler, P. M., \& Bonnet, D. C. (1980). Significance tests and goodness of fit in the analysis of covariance structures. Psychological Bulletin, 88(3), 588-606. https://doi.org/10.1037/0033-2909.88.3.588

Billig, M. (1989). The argumentative nature of holding strong views: A case study. European Journal of Social Psychology, 19(3), 203-223. https://doi.org/10.1002/ejsp.2420190303

Brown, J. D. (2000). What is construct validity? Shiken: JALT Testing \& Evaluation SIG Newsletter, 4(2), 8-12. http://hosted.jalt.org/test/bro_8.htm

Browne, M. W., \& Cudeck, R. (1989). Single sample cross-validation indices for covariance structures. British Journal of Mathematical and Statistical Psychology, 37, 62-83. https://doi.org/10.1207/s15327906mbr2404_4

Büyüköztürk, Ş. (2012). Örnekleme yöntemleri. Final notları. http://w3.balikesir.edu.tr/ $\sim$ msackes/wp/wp-content/uploads/2012/03/BAY-Final-Konulari.pdf

Büyüköztürk, Ş. (2018). Sosyal bilimler için veri analizi el kitabı istatistik, araştırma desen, spss uygulamalarl ve yorum. Pegem Academy.

Büyüköztürk, Ş., Çakmak, E. K., Akgün, Ö. E., Karadeniz, Ş., \& Demirel, F. (2016). Bilimsel araştırma yöntemleri. Pegem Academy.

Byrne, B. M. (1998). Structural equation modeling with Lisrel, Prelis and Simplis: Basic concepts, applications and programming. Lawrence Erlbaum Associates.

Can, A. (2016). SPSS ile Bilimsel araştırma sürecinde nicel veri analizi. Pegem Academy.

Çelik, A. (2010). Bilimsel tartışma esaslı ögretim yaklaşımının lise ögrencilerinin kavramsal anlamaları, kimya dersine karşı tutumları, tartışma isteklilikleri ve kalitesi üzerine etkisinin incelenmesi (Unpublished doctoral dissertation). Gazi Üniversitesi.

Çetin, P. S., Doğan, N., \& Kutluca, A. Y. (2014). The quality of pre-service science teachers' argumentation: influence of content knowledge. Journal of Science Teacher Education, 25(3), 309-331. https://doi.org/10.1007/s10972-014-9378-z

Çetin, P. S., Metin, D., Çapkınoğlu, E., \& Leblebicioğlu, G. (2016). Seeking the trace of argumentation in Turkish science curriculum. Science Education International, 27(4), 570-591.

Ceylan, E. (2012). İlköğretim beşinci sınıf öğrencilerine dünya ve evren ögrrenme alanının bilimsel tartışma odaklı yöntem ile ögretimi (Unpublished master's thesis dissertation). Gazi Üniversitesi.

Chen, Z., \& Yeung, A. S. (2015). Self-efficacy in teaching Chinese as a foreign language in Australian Schools. Australian Journal of Teacher Education, 40(8), 24-42. http://dx.doi.org/10.14221/ajte.2015v40n8.2

Chin, C., \& Osborne, J. (2010). Supporting argumentation through students' questions: Case studies in science classrooms. Journal of the Learning Sciences, 19(2), 230284. https://doi.org/10.1080/10508400903530036

Choi, A., Klein, V., \& Hershberger, S. (2015). Success, difficulty, and instructional strategy to enact an argument-based inquiry approach: Experiences of elementary teachers. International Journal of Science and Mathematics Education, 13, 9911011. https://doi.org/10.1007/s10763-014-9525-1

Durhan, G. (2018). Aristoteles retoriğinde kullanılan kanıtlamaların bilgi değeri. Beytulhikme: An International Journal of Philosophy, 8(2), 751-769. 
Ecevit, T., \& Kaptan, F. (2019). Fen bilimleri öğretmen adaylarının argümantasyon destekli araştırma sorgulamaya dayalı öğretim yeterliklerinin geliştirilmesi. Ilköğretim Online, $18(4), \quad$ 2041-2062. https://doi.org/10.17051/ilkonline.2019.639402

Er, S., \& Kırınd1, T. (2020). Argümantasyon tabanlı fen öğretiminin öğrencilerin bilimsel süreç becerileri ve akademik başarılarına etkisi. Gazi Eğitim Bilimleri Dergisi, 6(3), 317-343.

Erduran, S., \& Msimanga, A. (2014). Science curriculum reform in South Africa: Lessons for professional development from research on argumentation in science education, Education as Change, 18(1), 33-46. https://doi.org/10.1080/16823206.2014.882266

Erduran, S., Simon, S., \& Osborne, J. (2004). TAPping into argumentation: Developments in the application of Toulmin's argument pattern for studying science discourse. Science Education, 88, 915-933. https://doi.org/10.1002/sce.20012

Erika, F., \& Prahani, B. K. (2017). Innovative chemistry learning model to improve argumentation skills and self-efficacy. IOSR Journal of Research \& Method in Education (IOSR-JRME). 7(1) II (Jan. - Feb. 2017), pp. 62-68.

Erika, F., Prahani, B. K., Supardi, Z., \& Tukiran, T. (2018). Development of a graphic organiser-based argumentation learning (GOAL) model for improving the selfefficacy and ability to argue of chemistry teacher candidates. World Transactions on Engineering and Technology Education, 16(2), 179-185. https://doi.org/10.2991/miseic-19.2019.31

Erika, F., Supardi, Z. A. I., \& Tukiran, T. (2019, December). Development of student worksheet for improving the self-efficacy and ability to argue of chemistry teacher candidates study on junior high school students behavior based on Keirsey personality type [Paper presentation]. Mathematics, Informatics, Science, and Education International Conference (MISEIC 2019), Surabaya, Indonesia.

Erkol, M., Kışoğlu, M., \& Gül, Ş. (2017). Argümantasyon tabanlı bilim öğrenme yaklaşımı rapor formatının öğretmen adaylarının başarılarına ve fen bilgisi laboratuvarına yönelik tutumlarına etkisi. İlköğretim Online, 16(2), 614-627.

Eymur, G., \& Çetin, P. S. (2017). Argümantasyon tabanlı sorgulayıcı araştırma yönteminin öğretmen adaylarının fen öğretimi öz yeterlik inancına etkisi. Erzincan Üniversitesi Eğitim Fakültesi Dergisi, 19(3), 36-50. https://doi.org/10.17556/erziefd.315852

Fraenkel, J. R., Wallen, N. E., \& Hyun, H. H. (2011). How to design and evaluate research in education. McGraw-Hill.

Freeley, A., \& Steinberg, D. L. (2008). Argumentation and debate: Critical thinking for reasoned decision making. Engage Learning.

Garcia-Mila, M., Gilabert, S., Erduran, S., \& Felton, M. (2013). The effect of argumentative task goal on the quality of argumentative discourse. Science Education, 97(4), 497-523. https://doi.org/10.1002/sce.21057

George, D., \& Mallery, P. (2016). IBM SPSS statistics 23 step by step a simple guide and reference. Routledge Taylor \& Francis Group.

Ghebru, S., \& Ogunniyi, M. (2017). Pre-service science teachers' understanding of argumentation. African Journal of Research in Mathematics, Science and 
Technology

Education,

21(1),

49-60.

https://doi.org/10.1080/18117295.2016.1254493

Gurkan, G., \& Kahraman, S. (2018). Evaluation of pre-service science teachers' argumentation skills, knowledge levels and attitudes regarding organ transplantation and donation. European Journal of Educational Research, 8(2), 545-558. doi: 10.12973/eu-jer.8.2.545

Hasnunidah, N., Susilo, H., Irawati, M., \& Suwono, H. (2020). The contribution of argumentation and critical thinking skills on students' concept understanding in different learning models. Journal of University Teaching \& Learning Practice, 17(1), 1-11. https://ro.uow.edu.au/jutlp/vol17/iss1/6

Hechter, R. P. (2011). Changes in pre-service elementary teacher's personal science teaching efficacy and science teaching outcome expectancies: The influence of context. Journal of Science Teacher Education, 22, 187-202. https://doi.org/10.1007/s10972-010-9199-7

Heng, L. L., Surif, J., \& Seng, C. H. (2015). Malaysian students' scientific argumentation: Do groups perform better than individuals. International Journal of Science Education, 37(3), 505-528. https://doi.org/10.1080/09500693.2014.995147

Hewson, M. G., \& Ogunniyi, M. B. (2011). Argumentation-teaching as a method to introduce indigenous knowledge into science classrooms: Opportunities and challenges. Cultural Studies of Science Education, 6(3), 679-692. https://doi.org/10.1007/s11422-010-9303-5

Hiğde, E., \& Aktamış, H. (2017). Fen bilgisi öğretmen adaylarının argümantasyon temelli fen derslerinin incelenmesi: Eylem araştırması. İlköğretim Online, 16(1), 89-113. http://dx.doi.org/10.17051/io.2017.79802

Hu, L., \& Bentler, P. M. (1999). Cut off criteria for fit indexes in covariance structure analysis: Conventional criteria versus new alternatives. Structural Equation Modeling, 6, 1-55. https://doi.org/10.1080/10705519909540118

Iordanou, K., \& Constantinou, C. P. (2014). Developing pre-service teachers' evidencebased argumentation skills on socio-scientific issues. Learning and Instruction, 34, 42-57. https://doi.org/10.1016/j.learninstruc.2014.07.004

İnaltekin, T., \& Akçay, H. (2017). Argümantasyon temelli deney raporu yazımının fen bilgisi öğretmen adaylarının argüman yapılarını geliştirmelerine etkisinin incelenmesi. E-Kafkas Eğitim Araştırmalarl Dergisi, 4(3), 1-19. https://doi.org/10.30900/kafkasegt.359900

Jolliff, W. (1998). Text as topos: using the Toulmin model of argumentation in introduction to literature. Teaching English in the Two Year College, 25(2), 151158.

Karakaş, H., \& Sarıkaya, R. (2020). Çevre-enerji konularına yönelik gerçekleştirilen argümantasyon temelli öğretimin sınıf öğretmeni adaylarının argüman oluşturabilmelerine etkisi. Pamukkale Üniversitesi Eğitim Fakültesi Dergisi, 48, 346-373. https://doi.org/10.9779/pauefd.524850

Karakoç, F. Y., \& Dönmez, L. (2014). Ölçek geliştirme çalışmalarında temel ilkeler. Tip Eğitimi Dünyası, 40, 39-49.

Karslı Baydere, F., \& Şahin Çakır, Ç. (2019). Bilimsel süreç becerilerine dayalı laboratuvar uygulamalarının öğretmen adaylarının bilimsel süreç becerileri öz yeterliliklerine etkisi. Online Fen Ĕgitimi Dergisi, 4(2), 117-130. https://doi.org/10.25282/ted.228738 
Kaya, O. N., \& Kılıç, Z. (2008). Etkin bir fen öğretimi için tartışmacı söylev. Ahi Evran Üniversitesi Kırşehir Ĕ̈itim Fakültesi Dergisi (KEFAD), 9(3), 89-100.

Kazempour, M., \& Sadler, T. D. (2015). Pre-service teachers' beliefs, attitudes, and self-efficacy: A multi-case study. Teaching Education, 26, 247-271. https://doi.org/10.1080/10476210.2014.996743

Kelly, G. J., \& Takao, A. (2002). Epistemic levels in argument: an analysis of university oceanography students' use of evidence in writing. Science Education, 86(3), 314 342. https://doi.org/10.1002/sce.10024

Knaggs, C. M., \& Sondergeld, T. A. (2015). Science as a learner and as a teacher: Measuring science self-efficacy of elementary pre-service teachers. School Science and Mathematics, 115, 117-128. https://doi.org/10.1111/ssm.12110

Koçak, K. (2014). Argümantasyon tabanlı bilim öğrenme yaklaşımının öğretmen adaylarının çözeltiler konusunda başarısına ve eleştirel düşünme eğilimlerine etkisi (Unpublished master's thesis dissertation). Hacettepe Üniversitesi.

Köklü, N., Büyüköztürk, Ş., \& Çokluk, Ö. (2007). Sosyal bilimler için istatistik. Pegem Academy.

Kuhn, D., \& Udell, W. (2003). The development of argument skills. Child Development, 74(5), 1245-1260. http://www.jstor.org/stable/3696176

Lawson, A. (2003). The nature and development of hypothetico-predictive argumentation with implications for science teaching. International Journal of Science Education, 25(11), 1387-1408. https://doi.org/10.1080/0950069032000052117

Leech, N. L., Barrett, K. C., \& Morgan, G. A. (2005). SPSS for intermediate statistics: Use and interpretation. Lawrence Erlbaum Associates, Publishers Mahwah.

Leeman, R. W. (1987). Taking perspectives: Teaching critical thinking in the argumentation course. Paper presented at the Annual Meeting of the Speech Communication Association (73rd, Boston, MA, Nov. 5-8, 1987). (ERIC Document Reproduction Service No. ED 292147)

Liu, Q., Yin, C., \& Chen, B. (2021). Study on schedule risk assessment of power transmission and transformation project based on improved risk chain. IOP Conference Series: Earth and Environmental Science. 621. https://doi.org/10.1088/1755-1315/621/1/012018

Lytzerinou, E., \& Iordano, K. (2020). Teachers' ability to construct arguments, but not their perceived self-efficacy of teaching, predicts their ability to evaluate arguments. International Journal of Science Education, 42(4), 617-634, https://doi.org/10.1080/09500693.2020.1722864

Martín-Gámez, C., \& Erduran, S. (2018). Understanding argumentation about socioscientific issues on energy: a quantitative study with primary pre-service teachers in Spain. Research in Science \& Technological Education, 36(4), 463-483. https://doi.org/10.1080/02635143.2018.1427568

Menon, D., \& Sadler, T. D. (2016). Pre-service elementary teachers' science selfefficacy beliefs and science content knowledge. Journal of Science Teacher Education, 27, 649-673. https://doi.org/10.1007/s10972-016-9479-y

Ministry of National Education (MoNE). (2018). İlkögretim kurumlarl (ilkokullar ve ortaokullar) fen bilimleri dersi (3, 4, 5, 6, 7 ve 8. siniflar) öğretim programı. Ankara, Turkey. 
Mirza, N. M., \& Perret-Clermont, A. N. (2012). Introduction. In N. M., Mirza \& A. N., Perret-Clermont (Eds.), Argumentation and education theoretical foundations and practices (pp. 1-9). Springer.

Mulholland, J., \& Wallace, J. (2001). Teacher induction and elementary science teaching: Enhancing self-efficacy. Teacher and Teacher Education, 17, 243-261. https://doi.org/10.1016/S0742-051X(00)00054-8

Namdar, B., \& Tuskan, İ. B. (2018). Fen bilgisi öğretmenlerinin argümantasyona yönelik görüşleri. Hacettepe Üniversitesi Eğitim Fakültesi Dergisi, 33(1), 1-22. doi: 10.16986/HUJE.2017030137

Narayan, R., \& Lamp, D. (2010). “Me? Teach science?” Exploring EC-4 pre-service teachers' self-efficacy in an inquiry-based constructivist physics classroom. Educational Research and Reviews, 5(12), 748-757.

Ocak, G., \& Karakuş, G. (2015). Öğretmen adaylarının tartışma becerilerine ilişkin tutum ölçeği: bir ölçek geliştirme çalışması. Kuramsal Eğitimbilim Dergisi [Journal of Theoretical Educational Science], 8(1), 50-69. http://dx.doi.org/10.5578/keg.7967

Ogan-Bekiroglu, F., \& Aydeniz, M. (2013). Enhancing pre-service physics teachers' perceived self-efficacy of argumentation-based pedagogy through modelling and mastery experiences. Eurasia Journal of Mathematics Science \& Technology Education, 9(3), 233-245. https://doi.org/10.12973/eurasia.2013.932a

Osborne, J., Erduran, S., \& Simon, S. (2004). Enhancing the quality of argument in school science. Journal of Research in Science Teaching, 41(10), 994-1020. https://doi.org/10.1002/tea.20035

Özdem, Y., Ertepınar, H., Çakıroglu, J., \& Erduran, S. (2013). The nature of pre-service science teachers' argumentation in inquiry-oriented laboratory context. International Journal of Science Education, 35(15), 2559-2586. https://doi.org/10.1080/09500693.2011.611835

Özdem Yilmaz, Y., Cakiroglu, J., Ertepinar, H., \& Erduran, S. (2017). The pedagogy of argumentation in science education: science teachers' instructional practices. International Journal of Science Education, 39(11), 1443-1464. https://doi.org/10.1080/09500693.2017.1336807

Özlü, G., Keskin, M. Ö., \& Gül, A. (2013). Çevre eğitimi öz-yeterlik ölçeği geliştirilmesi: Geçerlik ve Güvenirlik Çalışması. Gazi University Journal of Gazi Educational Faculty (GUJGEF), 33(2), 393-410.

Öztürk, M. (2013). Argümantasyonun kavramsal anlamaya, tartışmacı tutum ve özyeterlik inancına etkisi (Unpublished master's thesis dissertation). Pamukkale Üniversitesi.

Pajares, F. (1997). Current directions in self-efficacy research. In M. Maehr \& P. R. Pintrich (Eds.), Advances in motivation and achievement (pp. 1-49). JAI Press.

Palmer, D. (2006). Durability of changes in self-efficacy of pre-service primary teachers. International Journal of Science Education, 28, 655-671. https://doi.org/10.1080/09500690500404599

Poulou, M. (2003). Influential factors on teaching efficacy: prospective teachers' beliefs. Paper presented at the British Educational Research Association Annual Conference, Heriot-Watt University, Edinburgh, 11-13 http://www.leeds.ac.uk/educol/documents/00003151.htm 
Purzer, S. (2011). The relationship between team discourse, self-efficacy, and individual achievement: A sequential mixed-methods study. Journal of Engineering Education, 100(4), 655- 679. https://doi.org/10.1002/j.2168-9830.2011.tb00031.x

Rachmatya, R., \& Suprapto, N. (2020). The correlation of scientific argumentation and critical thinking on global warming materials in Sman 19 Surabaya. Inovasi Pendidikan Fisika, 9(2), 192-199.

Ramey-Gassert, L., \& Shroyer, M. G. (1992). Enhancing science teaching self-efficacy in pre-service elementary teachers. Journal of Elementary Science Education, 4(1), 26-34. https://doi.org/10.1007/BF03173752

Rieke, R. D., \& Sillars, M. O. (1984). Argumentation and the decision making process. Scott, Foresman and Company.

Rosidin, U., Kadaritna, N., \& Hasnunidah, N. (2019). Can argument-driven inquiry models have impact on critical thinking skills for students with different personality types? Cakrawala Pendidikan, 38(3), 511-526. https://doi.org/10.21831/cp.v38i3.24725

Sadler, T. D. (2006). Promoting discourse and argument in science teacher education. Journal of Science Teacher Education, 17(4), 323-346. https://doi.org/10.1007/s10972-006-9025-4

Sampson, V., \& Blanchard, M. R. (2012). Science teachers and scientific argumentation: Trends in views and practice. Journal of Research in Science Teaching, 49(9), 1122-1148. https://doi.org/10.1002/tea.21037

Sampson, V., \& Clark, D. B. (2008). Assessment of the ways students generate arguments in science education: Current perspectives and recommendations for future directions. Science Education, 92, 447-472. https://doi.org/10.1002/sce.20276

Sandoval, W. A. (2003). Conceptual and epistemic aspects of students' scientific explanations. Journal of the Learning Sciences, 12(1), 5-51. https://doi.org/10.1207/S15327809JLS1201_2

Schumacker, R. E., \& Lomax, R. G. (2004). A beginner's guide to structural equation modeling. Lawrence Erlbaum Associates Inc.

Schunk, D. H., \& Meece, J. L. (2006). Self-efficacy development in adolescence. In F. Pajares, \& T. Urdan (Eds.), Self-efficacy beliefs of adolescents (pp. 71-96). Information Age Publishing.

Schunk, D. H., \& Miller, S. D. (2002). Self-efficacy and adolescents' motivation. In F. Pajares \& T. Urdan (Eds.), Academic motivation of adolescents (pp. 29-52). Information Age Publishing.

Schwarz, B. B., Neuman, Y., Gil, J., \& Ilya, M. (2003). Construction of collective and individual knowledge in argumentative activity. The Journal of the Learning Sciences, 12 (2), 219-256. https://doi.org/10.1207/S15327809JLS1202_3

Seçkin Kapucu, M., \& Türk, H. (2019). Güncel bilimsel haberlerin Toulmin argüman modeline göre incelenmesi ve öğrencilerin argüman düzeylerinin belirlenmesi. Eğitimde Nitel Araştırmalar Dergisi, 7(3), 1119-1144. doi:10.14689/issn.2148$624.1 .7 \mathrm{c} .3 \mathrm{~s} .10 \mathrm{~m}$

Simon, S., Erduran, S., \& Osborne, J. (2006). Learning to teach argumentation: Research and development in the science classroom. International Journal of Science Education, 28(2-3), 235-260. https://doi.org/10.1080/09500690500336957 
Simon, S., Richardson, K., \& Amos, R. (2012). The design and enactment of argumentation activities. In M. S. Khine (Ed.), Perspectives on scientific argumentation: Theory, practice, and research (pp. 97-114). Springer.

Sönmez, E. (2017). Argümantasyon tabanlı bilim öğrenme yaklaşımının fen bilgisi ögretmen adaylarının eleştirel düşünmelerine ve genel kimya başarılarına etkisi. Kastamonu Üniversitesi.

Taşkoyan, S. N. (2008). Fen ve teknoloji öğretiminde sorgulayıcı öğrenme stratejilerinin ögrencilerin sorgulayıcı ögrenme becerileri, akademik başarıları ve tutumları üzerindeki etkisi (Unpublished master's thesis dissertation). Dokuz Eylül Üniversitesi.

Tatar, M. K., \& Özenoğlu, H. (2018). Fen bilgisi öğretmen adaylarının bilimin doğası bilgisine ve öğretimine ilişkin öz-yeterlik inançları. Mehmet Akif Ersoy Üniversitesi Ĕ̈itim Fakültesi Dergisi, 46, 261-293. https://doi.org/10.21764/maeuefd.402689

Toulmin, S. (1958). The uses of argument. Cambridge University Press.

Tozlu, İ., Gülseven, E., \& Tüysüz, M. (2019). FeTeMM eğitimine yönelik etkinlik uygulamas1: Kuvvet ve enerji örneği. Yüzüncü Yll Üniversitesi Eğitim Fakültesi Dergisi, 16(1), 869-896. http://dx.doi.org/10.23891/efdyyu.2019.145

Trend, R. (2009). Commentary: Fostering students' argumentation skills in geoscience education. Journal of Geoscience Education, 57(4), 224-232. https://doi.org/10.5408/1.3559670

Tüzün, Ü. N., Bilir, V., \& Eyceyurt Türk, G. (2019). Ortaöğretim kimya dersi öğretim programı kazanımlarının Toulmin argüman modeli bileşenlerine göre değerlendirilmesi. Bolu Abant İzet Baysal Üniversitesi Eğitim Fakültesi Dergisi, 19(4), 1322-1333. https://dx.doi.org/10.17240/aibuefd.2020..-439202

Uçar, B., \& Demiraslan Çevik, Y. (2020). The effect of argument mapping supported with peer feedback on pre-service teachers' argumentation skills. Journal of Digital Learning in Teacher Education, 37(1), 6-29. https://doi.org/10.1080/21532974.2020.1815107

Ural, E., Öztaş, F., \& Ercan, O. (2020). Sınıf öğretmeni adaylarının sosyobilimsel bir konuda akıl yürütme tarzlarının ve argüman seviyelerinin incelenmesi. EKEV Akademi Dergisi, 24(82), 97-118.

van Eemeren, F. H., Grootendorst, R., \& Snoeck Henkemans, F. (1996). Fundamentals of argumentation theory: A handbook of historical backgrounds and contemporary developments. Lawrence Erlbaum Associates.

van Eemeren, F.H., Garssen, B., Krabbe, E.C.W., Snoeck Henkemans, F.A., Verheij, B., Wagemans, J.H.M. (2014). Handbook of Argumentation Theory. Springer Netherlands.

Velthuis, C., Fisser, P., \& Pieters, J. (2014). Teacher training and pre-service primary teachers' self-efficacy for science teaching. Journal of Science Teacher Education, 25, 445-464. https://doi.org/10.1007/s10972-013-9363-y

Voica, C., Singer, F. M., \& Stan, E. (2020). How are motivation and self-efficacy interacting in problem-solving and problem-posing. Educational Studies in Mathematics, 105, 487-517. https://doi.org/10.1007/s10649-020-10005-0

Von Aufschnaiter, C., Erduran, S., Osborne, J., \& Simon, S. (2008). Arguing to learn and learning to argue: Case studies of how students' argumentation relates to their scientific knowledge. Journal of Research in Science Teaching, 45, 101-131. https://doi.org/10.1002/tea.20213 
Walker, J., Sampson, V., Grooms, J., Anderson, B., \& Zimmerman, C. (2012). Argument-Driven Inquiry in undergraduate chemistry labs: The impact on students' conceptual understanding, argument skills, and attitudes towards science. Journal of College Science Teaching, 41(4), 82-89.

Walton, D. (2006). Examination dialogue: An argumentation framework for critically questioning an expert opinion. Journal of Pragmatics, 38(5), 745-777. https://doi.org/10.1016/j.pragma.2005.01.016

Woolfolk, A. (2016). Educational psychology. Allyn \& Bacon.

Zohar, A., \& Nemet, F. (2002). Fostering students' knowledge and argumentation skills through dilemmas in human genetics. Journal of Research in Science Teaching, 39(1), 35-62. https://doi.org/10.1002/tea.10008 


\section{Appendix 1:}

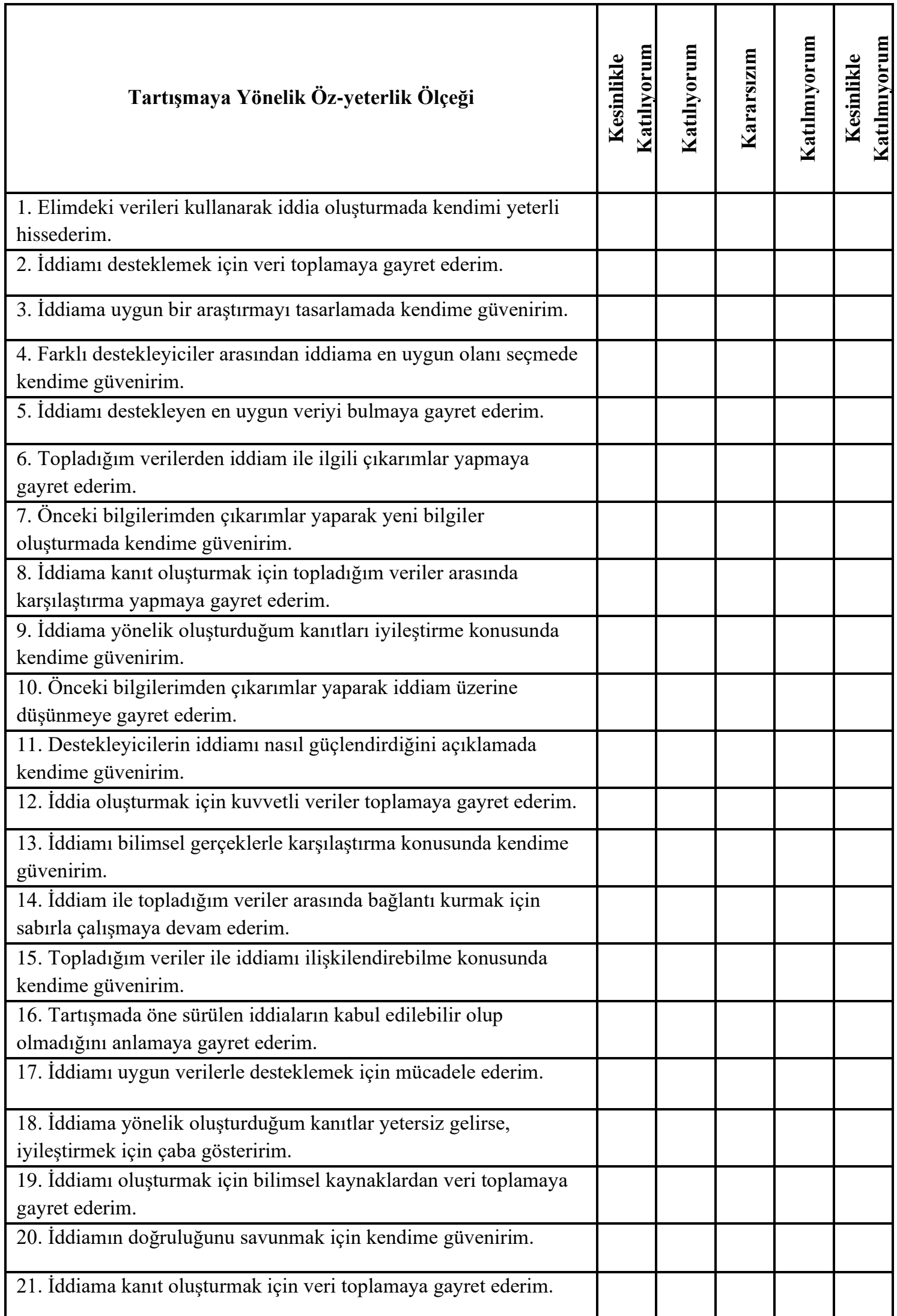

